\title{
‘Odd Girl Out’: An Interview with Valerie Mason-John, aka Queenie
}

\section{Emma Parker}

A writer and performer, Valerie Mason-John defines herself as a transracially-raised queer dyke of African descent. Born in Cambridge in 1962, she spent most of her childhood living in a Barnardo's orphanage in Essex after being passed into care by her single mother who had recently moved to Britain from Sierra Leone. After a disrupted youth and troubled adolescence, she began writing whilst studying Politics and Philosophy at the University of Leeds in the early 1980s. Motivated by the horror of the murders committed by Peter Sutcliffe ('the Yorkshire Ripper'), she became a founding editor of the feminist student magazine Jezebel. A political activist, she was a member of Women Against Violence Against Women and supported the Miners' Strike of 1984-5. Before completing her degree she moved to London to become a journalist, a role that offered an opportunity to pursue her interest in world affairs. She reported on events such as the Broadwater Farm Riot of 1985, the Nicaraguan Civil War, and the struggles against apartheid in South Africa. As an international correspondent, she also covered issues such as Aboriginal Land Rights and the deaths of black people held in custody in Australia. As well as working as a feature writer for the black national paper The Voice, she was a staff reporter for the national lesbian and gay Pink Paper, and co-editor of Feminist Arts News (1992-1997). She has also written for publications such as the Guardian, the Morning Star, and Capital Gay.

However, Mason-John gave up journalism on the grounds that 'it was impossible to tell true stories, the media didn't want the truth, and it was these stories I wanted to tell'. ${ }^{1}$ Seeking ways to tell stories more truthfully, she studied clowning and took a course at the Desmond Jones School of Mime and Physical Theatre, where she 'reclaimed the art of play...reliving some lost childhood years'. ${ }^{2}$ She started writing plays and through drama found liberation: 'I realised I could say anything I wanted in theatre, without it being censored before my audience got to see it'. ${ }^{3}$ Since she took up creative writing she has devoted herself to telling untold stories, particularly ones that subvert the myths that uphold the dominant ideologies of race, sexuality, gender, and nation. In a theatrical context, she is best known for her one-woman shows. Sweep It Under the 
Carpet was first performed in 1997 but revised as Brown Girl in the Ring in 1998 and republished in Deirdre Osborne's Hidden Gems (2008), a collection of six experimental plays by black British writers. ${ }^{4}$ Sin Dykes was first performed in 1998 and is published in Brown Girl in the Ring: Plays, Poems and Prose. ${ }^{5}$ Winner of the Mind Book of the Year Award, Mason-John's debut novel Borrowed Body (2005), republished as The Banana Kid (2008), bought critical acclaim in the realm of fiction. ${ }^{6}$ She has won several other prestigious prizes and awards: she was named one of Britain's Black Gay Icons in 1997, received a Windrush Achievement Award in 2000 for her artistic contribution to the Black and Asian communities, and was granted an honorary doctorate from the University of East London in 2007.7

Like Black Art and Culture on the Mainland of Europe (1992), a book that MasonJohn edited for the Arts Council of England, Brown Girl in the Ring challenges the disavowal of racial mixing and intermingling in European history. Inspired by stories she heard in Australia about photographs of white families that featured holes where the heads of aboriginal relatives had been cut out, and her discovery that Queen Sophia Charlotte, wife of King George III and great, great grandmother of Queen Victoria, had African ancestry, this one-woman show focuses on Regina, a black 'throwback' born to white parents due to polygenic inheritance (p. 304). ${ }^{8}$ The play traces the struggle for recognition and acceptance of this 'aristobrat' and 'odd girl out' (p. 308). Regina's parents are shocked and shamed by their daughter's skin colour - 'My poor Mamama never spoke again' and 'Dadada castrated himself' (p. 306 ) - and she is 'packed off to relatives - the Bollys of Ascot' (p. 307), where , as the play's refrain - 'Sweep it under the carpet' - makes clear, she is expunged from personal and public record. Exclusion is represented visually by the picture of a 'white royal-looking family' that is projected onto the stage since 'a head of someone is missing' (p. 293). As the royal family is coterminous with the nation, the play highlights the construction of the myth that Britain is a racially and ethnically homogenous place, one endorsed by the racist chant 'there ain't no black in the Union Jack' that Paul Gilroy takes as the title for his book on the relationship between race and nation. ${ }^{9}$ Verifying Mason-John's assertion that 'I could never have got away with telling this story as a journalist', ${ }^{10}$ several reviewers writing for national newspapers questioned that Queen Victoria was descended from a mixed-race lineage. However, The Sunday Times, eventually confirmed that the play was 
based on fact. ${ }^{11}$ Mason-John's unpublished play You Get Me (first produced in 2006) continues her exploration of hostile reactions to an inter-racial family, this time in a contemporary setting.

Whereas Brown Girl in the Ring concerns the connectedness of black and white subjects in a familial and national context, Sin Dykes explores sexual relationships between black and white women. Having co-authored with Ann Khambattta the first book to document the lives of black and Asian lesbians in Britain, Lesbians Talk: Making Black Waves (1993), which was followed by an edited collection of essays, Talking Black: Lesbians of African and Asian Descent Speak Out (1994), in this play Mason-John continues to challenge the myth that homosexuality is a white phenomenon by helping 'to make black lesbians visible'.12 As the title indicates, Sin Dykes affirms identities and desires previously regarded as sinful, shameful or taboo. In contrast to Ann Bannon's pre-Stonewall classic lesbian novel Odd Girl Out (1957), which focuses on Laura Landon, a shy college student whose wary attraction to women leaves her isolated and at odds with society, Mason-John's 'odd girls' are out and proud. Further, the play celebrates difference: as the title punningly suggests, the protagonists - who mostly inhabit a London club - are 'scene', not herd. The play also dramatises the tensions that developed between black lesbian feminist and queer politics in the 1990s. The notes that accompany the text explain: 'dykes are out of the closet. Black dykes openly do SM, dykes openly sleep with gay men. There is dialogue, debate, and outrage, but nobody is listening any more' (p. 41). In response to this situation, Mason-John's protagonists demand to be both seen and heard. Resisting what she calls 'the black lesbian thought police', ${ }^{13}$ which condemned inter-racial relationships as 'sleeping with the enemy', and the then prevalent lesbian view that penetrative sex is patriarchal, Mason-John explores the politics of pleasure through her representation of same-sex desire between black and white women, the use of dildos, and s/m sex. Like Patience Agbabi's poetry collection Transformatrix (2000), the play moves away from an earlier period in which, as Trudy notes, 'dykes seemed too frightened to talk about sex' and helped to establish a playful, sex-positive lesbian culture, asking complex questions about power without providing easy answers(p. 80). Sin Dykes was 
first performed at the Oval House Theatre in London, where it was a box-office sell-out, and has since been staged regularly throughout the world.

Where Sin Dykes addresses relationships between black and white women, The Banana Kid explores the relationship between 'black' and 'white' selves embodied by one girl, Pauline Charles, a black child brought up by white carers in a series of middleclass homes. The novel draws on Mason-John's own experience of growing up in a Barnardo's orphanage and, through its representation of transracial care, portrays an important aspect of black British history, one that - Mason-John notes - is 'missing from the predominant black British culture'. ${ }^{14}$ A fictionalised memoir, in The Banana Kid Mason-John transforms autobiography into art through the power of the imagination, endowing her story with a significance that exceeds the personal. Fiction also provides a means of portraying events too painful to relate directly.

The novel offers a compelling account of the racism endured by a black child living in a predominantly white British society in the 1970s, its title simultaneously indicative of Pauline's status as a 'Barnardo's kid' and an allusion to the racist comparison of black people to monkeys (p. 223). Stigmatised by racial difference in the children's home, Pauline is punished for being too English after being sent to live with her African mother, Wunmi, in London. Likewise, at her new inner city school, she is mocked by other black girls for 'speaking like the Queen' (p. 128), and ostracised for being 'a Bounty, a coconut...White inside, Black outside' (p. 125). Thus, although not mixed race, Pauline has to learn to negotiate a bi-cultural identity. This is a theme that Mason-John pursues in her forthcoming second novel I am Memoried. The Banana Kid, which has been described as 'the British Color Purple', 15 positioning Mason-John alongside the celebrated African American writer Alice Walker, is currently being adapted for the screen.

As Brown Girl in the Ring, Sin Dykes and The Banana Kid suggest, identity is a principal theme in Mason-John's work which persistently examines the interconnectedness of race, ethnicity, gender and nationhood from a woman-centred perspective that privileges female experience. Identity is presented as constructed and performative. As Gabriele Griffin notes, in Brown Girl in the Ring, the jigsaw pieces that 
scatter the stage, and the jigsaw throne symbolise both the construction and fragmentation of Regina's self. ${ }^{16}$ The suggestion that the jigsaw functions as a metaphor for identity is endorsed by the moment when Regina looks at one piece 'as if it were a mirror' (p. 307). The play traces Regina's attempt to win acceptance as a member of the English aristocracy by performing a hegemonic identity. Whereas initially she requests 'caviar...and rice and peas' (p. 297), foods that reflect her dual cultural heritage, she later asserts her preference for Handel's Messiah over 'reggae music' (p. 305). Also, when she takes her place on the thrown, declaring herself 'Queen of England', Beethoven's Für Elise 'blasts out' (p. 315), replacing the sound of 'Brown Girl in the Ring', the Boney M tune that she sings intermittently throughout the show.

If Brown Girl in the Ring reveals the elision of 'blackness' required to construct the nation as 'white', Sin Dykes highlights that 'black' is, as Stuart Hall insists, 'essentially a politically and culturally constructed category, which cannot be grounded in a set of fixed transcultural or transcendental racial categories and which therefore has no guarantee in Nature'. ${ }^{17}$ Griffin proposes that Sin Dykes repudiates essentialist and monolithic notions of 'the black woman' through its presentation of a range of different identities: 18 Trudy, the central character, is 'a Brixton babe' with a 'non-specific black British accent'; Kat is 'an afrekeke dyke' who speaks with 'a Jamaican accent'; and Clio is an 'Essex girl' with a 'Cockney' accent (p. 42). Kat highlights the self-conscious adoption of an Afrocentric identity. Kat is an 'African-Caribbean' woman who adopts patois to communicate her identification as an 'African sistah' (p. 48). However, she slips into London slang when angry - 'Are you off your box or what?' (p. 56). ${ }^{19}$ In addition, when her Afrocentricism is compromised by contradictions in her political ideology (Kat is critical of Trudy for sleeping with white women and condemns SM sex but it transpires that she has secretly had sex with Gill, a 'self-defined SM dyke' (p. 55), and uses handcuffs in her 'play' with another white woman, BD), Trudy tells her to 'Cut the patois' (p. 81). Further, Gill - a white woman - speaks patois just as well as Kat. When she warns Trudy that 'Kat will cuss your clart' (p. 72), Trudy responds, 'Cha so you tink your black now?' (p. 72). ${ }^{20}$ Indeed, Sin Dykes invokes an essentialist conception of race and ethnicity in order to challenge it. Kat's assertion that 'Black women don't / do SM' because it is 'not in our genes' (p. 79) is subverted by her own analysis of the historical and political reasons why she finds SM problematic: chains and handcuffs offer an 
uncomfortable reminder of slavery and a racist criminal justice system that has put three of her brothers 'behind bars' and restrained a fourth in a psychiatric unit (p. 59).

Further illustrating a non-essentialist conception of race, ethnicity and culture, in The Banana Kid, Pauline learns what Claire E. Alexander calls 'the art of being black', through which identity is 'created and re-created as part of an ongoing and dynamic process'. ${ }^{21}$ At her inner city school, Pauline drops her 'posh voice' (p. 132) and later learns 'pidgin English' from her half-sister Shola who arrives from Nigeria to live with Pauline and her mother (p. 160). Shola also puts Pauline's hair into 'cane row, inside-out corn row and china bumps' (p. 163) instead of 'bunches' (p. 106). After being taken from Wunmi and placed in another home, Pauline meets Alexis, who teaches her how to swap 't's for d's' and say 'deres, dese, dat and dem' (p. 182), to suck her teeth, to wear a headscarf, and dance to soul and reggae. At grammar school, Pauline performs her 'black' identity for a white audience by speaking patois with Sadie, the only other black girl present, and mimics the pose of Jamaican 'rude boys', simultaneously highlighting the performativity of race and gender: 'We show off and step into our starring roles most lunchtimes' (p. 204). However, while she embraces a 'black' self, Pauline is unable to deny the double vision that Susheila Nasta describes as the product of her own position as the daughter of an Indian father and English mother. ${ }^{22}$ Thus the novel questions the idea of an authentic form of blackness, one based on the exclusion of whiteness and Englishness, echoing Jayne 0. Ifekwunigwe's call for a model of coming to terms with blackness that does not require a mixed-raced or transracially-raised subject to sever ties with her white, English roots. ${ }^{23}$ In the 'Hole' (p. 220), a remand centre where Pauline is sent to await her sentence for shoplifting, one inmate remarks that she is whiter than her white friend Sherry: 'You're so fucking posh and Miss Prim-andProper. You should be white and her black' (p. 226). Simultaneously both 'black' and 'white', Pauline epitomises 'the crisscrossed circuitry of cross-identification' that José Esteban Muñoz associates with queers of color, and her dual identity makes her a cultural 'terrorist' in the sense that she performs 'the nation's internal terrors around race', particularly fears about the transgression of boundaries. ${ }^{24}$ In this sense, MasonJohn transforms her 'banana kid' from monkey into guerrilla. 
An interrogation of the constructedness of ethnic and racial identity is accompanied by a questioning of the essentialist norms of gender. Brown Girl in the Ring was inspired by a workshop conducted by Lois Weaver, co-founder of the lesbian feminist theatre company Split Britches, renowned for producing satirical, genderbending shows, and employs exaggeration to create a drag aesthetic that exposes the artificiality of femininity. ${ }^{25}$ Thus, although the sexuality of the protagonist remains unspecified, the play can be termed 'queer' in its deployment of what Muñoz terms an 'excess effect' that works to destabilise the world of 'pasty normals'. ${ }^{26}$ Adopting the role of ballet dancer, the epitome of feminine grace, Regina appears on stage wearing a 'ballet dress with several petticoats underneath and bloomers', ballet shoes, a white courtier's wig and 'jewels fit for a queen' (p. 293). She speaks in an 'exaggerated' upperclass English accent (p. 297). The wig that, like her accent, denotes Regina's class status in the context of aristocratic society also makes her look like a contemporary drag queen, and the performativity of gender is stressed by her 'highly stylised' (p. 297) movements and the adoption of various poses, which echo the contemporary fashion for 'voguing' in queer culture, a key feature of the African American and Latino drag balls chronicled in Jennie Livingston's documentary Paris is Burning (1990). After taking the part of Regina, Mason-John became known as 'Queenie', a persona she has embraced as a performer and an educator in order to differentiate her journalism from her work in other spheres, but one that also challenges the legacy of colonialism, which forces many black people 'to live in a class lower than our real one'. ${ }^{27}$ Mason-John's 'aristocratic self' is likewise reflected in her playful description of her role as resident presenter of the pilot television show South Thames Live: 'I'm Lady of the manor!'28

Sin Dykes unsettles the binary norms of gender, sex and sexuality. The Diva bar, the backdrop of much of the action of the play, is populated by several 'funeral and diesel dykes' (p. 48), and Butch characters like BD, who is - as her name indicates - 'a bull dyke lesbian', and Trace, who is 'laddish' (p. 42), epitomise what Judith Halberstam terms 'lesbian counterproductions of female masculinity' that contest the 'privileged reservation of masculinity for men'. ${ }^{29}$ As Kat's account of 'genderbending courses' suggests, masculinity is not a natural expression of maleness but a performance that can be adopted by women or men: 'They'll teach you how to strap your breasts down, don a tash, and how to bulge in the right places' (p. 54).Through her focus on black butches, 
Mason-John echoes Halberstam's point that masculinity, typically rendered invisible through a process of reification, becomes legible 'where and when it leaves the white male middle-class body'. ${ }^{30}$ The play's subversion of gender boundaries is extended by the man that Trudy mistakes for a woman, an error which elicits Gill's assertion that 'the best looking dykes are gay boys' (p. 50). While the representation of black women in butch roles undercuts heteropatriarchal gendered binary oppositions, the portrayal of femme black lesbians also challenges the racial stereotype of black women as sexually assertive. As Mason John explains, 'During my twenties, I felt an unspoken pressure to be butch in bed from white women, as if we, black women, had to be sexually dominant'. ${ }^{31}$ Further, Sin Dykes presents lesbian butch/femme identities as mutable rather than mutually exclusive. Gill, for example, is 'butch/femme on the streets, butch between the sheets' and Trudy, although a 'femme' (p. 42), dons a dildo. Likewise, when BD removes her trousers, she reveals 'sexy suspenders' (p. 60).

The fluidity and plurality of gendered subjectivities portrayed in Sin Dykes reflects the mobility of Mason-John's own gendered sense of self: once 'a go-go dancer, clad in top hat, tails and a strap-on dildo',32 she also appears in Del LaGrace Volcano and Ulrika Dahl's Femmes of Power: Exploding Queer Femininities (2008). As she comments, 'Queer culture had a huge impact on me when I realised I could be a femme one day and something else the next'. ${ }^{33}$ An interest in non-normative genders is further marked by her role in the 1990s as Director of the Pride Arts Festival and Artistic Director of London's Mardi Gras, the UK's biggest celebration of lesbian and gay lives, and as host as Queenie - of Britain's first Drag King competition at London's National Film Theatre in 1995, a cheeky response to 'lesbian chic', which, Mason-John avers, compels women 'to conform to an image that is ultimately acceptable and non-threatening to men'. ${ }^{34}$ Likewise, Britain's first national 'Alternative Lesbian Beauty Contest', organised and hosted by Queenie in 1998, celebrates the diversity of women's queer identities and challenges the narrowness of dominant definitions of 'beauty' through the categories 'butch', 'femme', 'drag king', 'pierced and tattooed, 'mature' and 'women of colour'.

Subverting the heteropatriarchal view that lesbians are pseudo-men, Sin Dykes, also illustrates that the phallus signifies might rather than maleness. Trudy borrows her dildo from Gill, and Clio and Trace both wear a dildo under their clothes, a practice known as 'packing' (p. 53). As she teaches Trudy how to wear a dildo, Gill tells her, 'Go 
on, move your hips a bit. Get comfortable, get familiar. Get in touch with its power' (p. 76). Indeed, as Judith Butler has shown, the lesbian phallus constitutes not an imitation of maleness but a subversion of sexual difference. In Bodies That matter (1993), Butler draws on Freud's notion of the imaginary contours of the bodily ego, and Lacan's proposition that the morphology of the body is a 'psychically invested projection, an idealization or fiction', to argue that the phallus is 'an imaginary effect' and a 'transferable and plastic property'. ${ }^{35}$ Because morphologies are projected, variable projections and modes of delineating and 'theatricalising' body surfaces are possible, such that body surfaces or bodily egos may become sites of transfer for properties that no longer properly belong to any anatomy. ${ }^{36}$ Exemplifying Butler's theory, the dildos worn by Mason-John's female characters demonstrate that identifications that cross gender boundaries 'reinstitute sexed bodies in variable ways' and 'reconfigure the mapping of sexual difference itself'. ${ }^{37}$ The lesbian phallus subverts the binary categories of both sex and sexuality. As Kat explains to Trudy, 'One thing you've got to understand about some of these 1990s white girls is that they say it's alright to screw a man and call yourself a dyke. It's the phase at the moment, packing a dildo down their Calvin Klein's, and picking up cute looking gay men. It's all the rage. They call it queer' (p. 53).

The Banana Kid likewise subverts binary categories of gender. In her essay, 'My Awakening to Lesbianism', Mason-John highlights the forceful imposition of gender norms when she reveals that her biological mother beat her for expressing a desire to be a boy as well as for not being African. ${ }^{38}$ Likewise, in The Banana Kid, Aunty Morag is disconcerted by Pauline's desire to play outside and get her clothes dirty. Worrying that she is 'different from the other girls' (p. 17), she urges Pauline to 'start playing with dolls in the nursery' (p. 22). However, Pauline subverts the conventional categories of gender. A tomboy who wears her hair 'cropped like a boy' (p. 106), she rejects the trappings of conventional femininity - 'no earrings' (p.106) - wants to be 'an aeroplane pilot' (p. 105), and is attracted to other tomboys, like Theresa, who prefers to be called 'Terry' (p. 42).

While Mason-John forms part of what R. Victoria Arana sees as a new (post1996) wave of black British writers who reinvent and redefine what it means to be British, she is specifically preoccupied with the ideology of Englishness. ${ }^{39}$ Brown Girl in 
the Ring challenges the association of Englishness with whiteness when Regina asserts, 'I am as English as Her Majesty' (p. 297). In The Banana Kid, Pauline initially internalises dominant definitions of Englishness that demand that she denies her blackness (like Regina in Brown Girl). She tries to scrub off her black skin, chalks and flours herself, and even douses herself in bleach. Later, to embrace her blackness, she denies her Englishness. When she learns that 'Inglis' is regarded as a derogatory term in the black community (p. 129), she starts 'talking Jamaica' (p. 205). However, ultimately, Pauline accepts that she is both black and British. The novel further debunks the myth of national and ethnic purity through Pauline's 'English' family, which includes Uncle Boris, a German Jew, and Aunty Morag, whose name suggests she is a Scot. Moreover, the Barnardo's home, 'where most of us aren't sure where we really come from' (p. 131), serves as a microcosm of England, a culturally hybrid and genetically diverse nation shaped by Roman, Saxon, and Norman influences. Mason-John continues to reflect on Englishness in her blog, where she notes that even the rose, often regarded as the epitome of Englishness, comes from Persia. ${ }^{40}$

Home and family are other central preoccupations. The Banana Kid follows a number of classic black and lesbian texts such as Toni Morrison's The Bluest Eye (1970), Alice Walker's The Color Purple (1982), Dorothy Allison's Bastard out of Carolina (1992), and Sapphire's Push (1996), recently filmed as Precious (2009), in questioning the dominant ideal of home as a place of safety and security for girls. In Mason-John's work, home is frequently the site of trauma, and the impact of acute psychological distress is a persistent concern. Her first show, Body Politics (produced in 1991), explores the relationship between sexual abuse, rape and eating disorders. ${ }^{41}$ Brown Girl in the Ring delineates the psychological damage caused by the negative, stereotypical views of blackness internalised by Regina: 'I look like the fly/ In the milk, milk, milk' (p. 300), 'I look like the alien / From Mars Mars Mars'; 'I look like the golly / On the jam jar jar jar' (p. 309); 'I look like the mould / In the cheese cheese cheese' (p. 310). Repetition creates the effect of a stammer, a common symptom of trauma. Psychic distress is also indicated by Regina's 'hysterical laughter' (p. 306) and the invention of an imaginary friend, 'Lizard'. However, rather than endorsing the views espoused by Regina's psychiatrist, who pathologizes blackness by suggesting that 'negroes' are 'manic', stupid 
and 'aggressive' (pp. 313-4), Brown Girl in the Ring highlights the harm caused by dominant ideologies of race.

For Pauline in The Banana Kid, home is the location where she is bullied, sexually abused, and beaten. She creates a series of imaginary friends - Sparky, Angel, and Snake - who express her distress by forcing her to behave in disruptive ways and reflect her fractured sense of self. Seeking to escape her stigmatised black body, the sexual abuse she is subjected to by other children in the home, and the physical violence she suffers at the hands of her sadistic, mentally unstable mother, Pauline has out-of-body experiences. Like her imaginary friends, who offer the support she needs to survive an intensely painful situation, splitting and dissociation are psychological strategies that she develops to cope with trauma, also suggested by her tendency to sleepwalk. Related from Pauline's perspective, the novel captures a child's consciousness through the use of a first person narrative. By telling the story in the present tense, Mason-John conveys the way that children tend to live in the moment, although being in the present is also a state of consciousness that can be achieved through meditation, a practice that MasonJohn links to healing in her self-help book Detox your Heart (2005). ${ }^{42}$ The use of the present tense thus simultaneously creates a sense of immediacy that makes it impossible for readers not to empathise with Pauline's plight and hopefully signals her potential for healing.

Challenging the conservative ideal of the nuclear unit, Mason-John also refashions family. In Sin Dykes, for example, a queer community offers an alternative model of kinship, an extended family founded on community rather than biology. Similarly, The Banana Kid queers the traditional family: in the Barnardo's home, Pauline has three non-biological house parents, including two maternal figures: Aunty Claire, her husband, Uncle Boris, and Aunty Morag, the cook. Although Mason-John redefines the conventional structures of kinship and community, her Christmas show, The Adventures of Snow Black and Rose Red (first produced 2001-2), which was written for a family audience, suggests that family is a concept she continues to cherish.

Nonetheless, a sense of homelessness haunts Mason-John's queer, black, female protagonists. The Banana Kid explores the painful impact of deracination and 
transracial care - the trauma of growing up with what Lemn Sissay (another transracially raised black British writer) punningly calls 'No next of skin' in his poem 'Before We Get Into This'. ${ }^{43}$ Dislocated from both her mother's country and her biological family, Pauline experiences an acute sense of loss, and her metaphorical homelessness is reflected in and compacted by her literal homelessness when she runs away to live on the streets. Avtar Brah proposes that diasporic narratives often articulate what she terms 'homing desires', 44 the struggle to locate a site of belonging. Likewise, Ann-Marie Fortier suggests that queer subjects experience exile and estrangement which locates them outside the confines of home in its various forms (family, nation). ${ }^{45} \mathrm{~A}$ black girl brought up in care who begins to explore her sexuality at the end of the novel when she falls in love with a female prison guard, Pauline epitomises the metaphorical homelessness of the queer diasporic subject. However, The Banana Kid points to the positive potential of unbelonging and endorses both Fortier's assertion that movement can be the basis of new forms of identity and James Proctor's contention that for the diasporic subject 'dwelling constitutes a kind of para-site, within travel'. ${ }^{46}$ Reflecting this, the novel ends on an uplifting note as Pauline leaves prison and begins a journey to an unspecified destination that is full of possibility: 'My heart beats fast as I watch the green pastures whiz by' (p. 244).

While Mason-John's work explores what it means to be 'black, woman, and lesbian in Britain', ${ }^{47}$ she protests 'the notion that black writers can only write for and about black characters'. ${ }^{48}$ Being a journalist not only taught her to write concisely, she says, but also enabled her 'to write about everything'. ${ }^{49}$ A refusal to be confined - to be a brown girl ringed - has shaped her relationship to form as well as content, and her work epitomises the 'unsettling, recombination, hybridisation and "cut-and-mix"' that defines a diaspora aesthetic. ${ }^{50}$ She has worked in various media and written in diverse forms, often across literary genres. She has presented her work on both page and stage, relishing the opportunity to exploit sight and sound. She has performed in plays produced by Talawa, Britain's leading black theatre group, and participated in events at Word Up Women's Cafe, a space for performance poets. ${ }^{51}$ Reflecting her interest in diverse artistic forms, Mason-John's show Surfing the Crone, produced in conjunction with the Institute of Contemporary Arts (1997), drew her into collaboration with the choreographer Delta Streete and the musician Nigel Shaw. Similarly, The Adventures of 
Snow Black and Rose Red combines pantomime and carnival, fusing African, Caribbean, and Asian mythology to revise a classic European fairy tale. The show drew on pantomime's tradition of cross-dressing and rewrote the conventional heterosexual fairy tale plot to create a multicultural and queer show suitable for adults and children alike. After taking an MA in Creative Writing at Sussex University, Mason-John has also developed an interest in classic literary forms. This led to The Perfect Road (first produced in 2004), a one-woman show that simultaneously employs and subverts canonical forms by using the sonnet and villanelle, conventionally associated with romantic love, to represent child sex abuse.

Throughout her work, Mason-John repeatedly defies the conventions of realism, resisting the normative (white, male, heterosexual) perspective that realism presents as real and true. ${ }^{52}$ As the stage directions indicate, Sin Dykes shatters the 'fourth wall' that separates actors and audience at the outset: 'The audience enter into a clubby atmosphere and are frisked by $B D$, the owner of the bar' (p. 43). Such a technique, which renders the audience active participants rather than passive observers, encourages people who have come to see the play to feel implicated in the action and to take responsibility for the issues raised. Like Sin Dykes, Brown Girl in the Ring uses mime and physical theatre, and The Banana Kid employs magic realist elements to reflect a child's imaginary world. In this sense, the novel is psychologically realistic even though it eschews realism. The theme of reincarnation, which gave the novel its original title (Borrowed Body), pulls The Banana Kid further away from a mainstream tradition of literary realism, as do Pauline's recurrent dreams about a Yoruba chief surrounded by ivory and gold, a figure that (subverting the boundaries of gender) transpires to be her former self - a man who sold his own people into slavery. The theme of spirits and reincarnation reflect Mason-John's cross-cultural influences. As she explains: 'When I was very young, my house parents used to do a ouija board after we went to bed, so I knew about poltergeists. And my mum did obeah. So both from a white European's perspective and from an African perspective, I was open to the spirit worlds'. ${ }^{53}$ Ordained into the Western Buddhist Order in 2005, the theme of reincarnation is also informed by Eastern philosophy. The representation of Africa in a non-realist mode in The Banana Kid, repeated in her short story 'Toxins', 54 a fable that features speaking 
snakes, suggests that Africa figures in Mason-John's work as what Salman Rushdie terms an 'imaginary homeland'. ${ }^{5}$ Pursuing her subversion of realism, in Mason-John's next novel one of the narrators is a plant.

Whilst continuing to write creatively, Mason-John also teaches creative writing she was Writer in Residence at Holloway Prison (2005-6) - and now works as a trainer in anger management and conflict resolution based in Edmonton, Canada. This work lead to Detox your Heart, a self-help book about working with anger, fear and hatred, which examines in non-fictional form themes similar to those explored in 'Toxins', a short story about the destructive effects of negative thoughts and feelings. Her latest book, Broken Voices: 'Untouchable' Women Speak Out (2008), demonstrates her continuing commitment to women's issues and global politics.

EP: In Lesbians Talk: Making Black Waves and Talking Black: Lesbians of African and Asian Descent Speak Out you delineate a conflict between black lesbian feminist and queer politics. Does that conflict still exist in your view?

VMJ: It's not as marked as it was in the 1990s, when 'queer' was a term associated with white, gay North American men. Many black women do now identify as queer. These are women, often a younger generation of women, who play with gender.

EP: What does 'queer' mean to you? Is it a term that you embrace?

VMJ: 'Queer' is an interesting term because its meaning keeps on changing. Since the 1990s, the lesbian community has claimed it. But 'queer' doesn't just mean 'homosexual', it encompasses a range of identities, gay and straight. It includes bisexual and transgender people. 'Queer' covers a whole range of sexualities and genders. It means 'other' or 'different'. It's a political term that permits greater freedom around gender and sexuality. 'Queer' indicates identities that are fluid. It loosens the attachment to binaries. For example, some lesbians date transgender men. What does that mean in terms of their sexuality? We live in a moment when a black man has become president of the USA. It feels like a time when anything is possible, and queer 
reflects that. Queer is liberating. 'Queer' is different to 'gay', which is a term that applies to homosexual people who live lives that are acceptable to the heterosexual community. I don't like labels, which can be restrictive as well as liberating. I was given my first label at age 5: 'orphan'. Labels relating to race and gender came later. Still, I'm attached to the label 'dyke', even though it's so last century and, despite that attachment, yes, I do see myself as queer.

EP: Does 'queer' entail any limitations or impose its own hegemonies in your view?

VMJ: Limitations are inevitable. As a child queer meant 'strange' or 'different' but it's increasingly seen as normal. It's entered the mainstream, it's moved from the street into the academy. Queer enables academics who are straight to write about homosexuality, and men to teach Women's Studies. Queer hasn't necessarily diluted gay politics and women's politics but it has changed them.

EP: What about the label 'feminist'?

VMJ: I feel privileged to have had the luxury of benefitting from the impact of feminism. Feminism seeks justice for women and the end of sexism, misogyny and patriarchal oppression in all its forms throughout the world. Feminism helped me to discover myself as a young woman. Having been raped, sexually abused, and silenced as a girl, I was an angry adolescent. Feminism allowed me to express this anger in a safe space, although I wouldn't say that feminism is about anger. It was the beginning of my healing as a black woman and the cultivation of self-love. When I heard that Andrea Dworkin had died in 2005, I rushed out and bought every paper. Although I haven't always acknowledged it, I realised then that feminism had played a large part in shaping who I am today. I mourned the loss of a feminist heroine, someone who had contributed so much to feminist theory.

EP: Have race and sexuality complicated your relationship to feminism?

Early on, I felt a resistance to feminism because it didn't speak about my individual experience as a black woman. As I became more aware of my black self, I felt alienated from white culture. bell hooks was the only feminist theorist that I identified with 
during that time. Her book Ain't I A Woman? liberated me. I realised I could be a feminist and be black. I didn't have to choose being black over being a woman anymore. They are both just as important to me. I also discovered feminists who were actively conscious about a feminist politics that included race, class, disability, globalisation, human rights, sexuality, sex work, the body, reproduction and much more. Joining a black-only lesbian feminist group was also part of my discovery of my black self. However, I wasn't able to embrace black lesbian feminist separatism wholeheartedly because my mothers had been white, and they were the first women I had learned to love. Becoming a black lesbian feminist separatist would have meant denying a part of my self. Black lesbian separatists also accused me of sleeping with the enemy for having white lovers.

I have felt equally restricted by the black and white lesbian feminist community. My book Talking Black delighted the black lesbian feminist community and upset some white lesbian feminists. In Making Black Waves, the chapter 'Racism in the Margins' opens, 'All White people are racist, because they are socialised by western societies riddled with prejudice and ignorance'. Because this was the first book on black and Asian lesbian culture, white women did not feel they could damn it. But when Talking Black was published, white women vented their anger. It was okay for me to write that all men are sexist, but writing that all white women are racist was considered sacrilege. In the early 90s I was straddling white feminism and black feminism, and trying to work out if it was it better to be oppressed by my white sisters or my black brothers.

EP: How did the black community respond to your books about lesbian feminism?

VMJ: After we wrote Lesbians Talk, I remember saying to Ann Khambatta, tongue in cheek, 'I'll always have to be a lesbian writer now'. I didn't realise that book would have such a huge impact on my career as a journalist. In the black community I went from being a serious writer who had given talks with John Pilger, Stuart Hood, and Marc Wadsworth to being forced underground. Despite the fact that I had almost secured an interview with Margaret Thatcher, until her office backed out during the 1987 election, I was no longer called up or commissioned to write articles for the black media. Doors closed. So I went into the gay press, where I ended up struggling to get black stories covered. However, feeling that my career as a journalist was over left me free to write 
Sin Dykes, which incorporates all aspects of my feminist black lesbian self. To my surprise, black and white lesbians loved the play.

EP: How has feminism shaped your work?

Feminism has affected my writing practice. My first show, Body Politics, was inspired by Ntozake Shange's play For Colored Girls Who Have Considered Suicide when the Rainbow is Enuf (first produced in 1975 and published in 1977). The poems in Brown Girl in the Ring initially formed the basis of my show Surfing the Crone, which was inspired by Clarissa Pinkola Este's book Women Who Run with the Wolves: Myths and Stories of the Wild Woman Archetype. Also, Brown Girl in the Ring follows that feminist tradition of bringing to light women lost in history. Feminism, which is about putting women back on the map, is at the heart of my work, although Buddhism is another influence now. Detox Your Heart grew out of my Buddhist practise, as did Broken Voices, my book about Dalit women. I like to feel that, as a writer, I can write about anything, but feminism is always there as an undertone. So, yes, feminism has most definitely shaped my beliefs and all my writing is informed by feminism in some way.

EP: You've written about your love of music, particularly blues, soul, funk and rave. In what ways does music reflect your cross-cultural heritage?

VMJ: Clubbing has been a very big part of my life. The first clubs I went to were Rock and Roll clubs, and I was a Teddy Girl. I was one of very few black Teddy Girls around at that time, and I used to get a lot of shit on the streets from other black people because rock and roll was considered white, but I discovered that it was a black musical form that had been appropriated by white artists. In the 1970s, clubs were part of a very white music scene in Britain. To get in, you had to not look like a typical black person, you had to look different, so when I was 17 I dyed my hair green, and that got me in. Also, I was very much one of Isaac Julien's young soul rebels. ${ }^{56}$ Diasporas have had a great impact on English culture. You see the fusion of cultures on the streets, in shops and in fashion, but it's most clear in music. 
EP: Brown Girl in the Ring invokes the Boney M song. Is music an influence on your creative work?

VMJ: A sense of rhythm is important. A good DJ will take clubbers on a journey similar to Gabrielle Roth's 5 Rhythms: flowing, staccato, chaos, lyrical, stillness. That's the journey I want to take my readers or audience on.

EP: Were your literary influences as cross-cultural as your taste in music? You've said that Paule Marshall, Audre Lorde, Toni Morrison, Barbara Burford and Bernardine Evaristo inspired you. Which other writers had an impact?

VJM: Enid Blyton's books were a big influence on me. I identified with George, the tomboy in the Famous Five stories, and Barnabas, the itinerant circus-boy in The Barney Mysteries who didn't have a family. Forster's A Passage to India, which foregrounds race, and Hardy's The Return of the Native, which is about a small community, and what happens to people when they try to move away, both resonated with me. Suniti Namjoshi is one of my heroines. She's a brilliant writer. The historians C.L.R. James and E.P. Thompson were also an influence. I saw a film of these two great men -one black and one white - in conversation. Initially, I wanted to be a historian.

EP: How do you see your work in relation to that of other Black British writers such as Jean 'Binta' Breeze, Grace Nichols, Benjamin Zephaniah, Linton Kwesi Johnson, Beryl Gilroy, and Merle Collins? In what ways does your work emerge from theirs?

VMJ: These writers have been my role models. As a journalist, I interviewed most of them about their work before becoming a poet and fiction writer myself. They are inspirations - Linton Kwesi Johnson and Benjamin Zephaniah especially, as they wrote in a vernacular that brought back memories of toasting in blues and shabeams, where I spent much of my teens and twenties. ${ }^{57}$ This is where I found the inspiration to tell stories. In shabeams, someone would just get on a mike and toast over a record, and you would hear stories about what was happening in the black community and get the politics. It was uplifting and liberating. Today's hip hop originates from toasting. I do use black English in some of my work - as this was one of the English vernaculars that I 
was immersed in during my adolescence. So these writers have helped me to find my own unique voice. This has been hard because, growing up, I didn't know who I was and I had to discover my voice as a writer. I was very English, passed as white, culturally, and didn't feel 'authentic' speaking patois, so I was stifled for a while. Finding my voice meant accepting my Englishness whilst still being black.

EP: You've said that black British writers no longer have to borrow from the African American experience to shape their aesthetic . Can you explain how you see the difference between the two?

VMJ: The African American experience is one of slavery. Africans were taken from the continent and placed in America as far back as the 1500s, so African Americans have a long history. In the UK, our history is different. We were taken as slaves and repatriated in the Caribbean and, although there were few of us in Britain from 1500s, and even earlier, we didn't come en masse until the 1950s. Therefore, we have limited generations; we don't have the history. I am part of the first 'out', visible, ageing black lesbian and gay community in Britain. Also where African Americans have civil rights leaders like Marcus Garvey, Martin Luther King, Malcom X, Rosa Parks, and many more, Britain has not cultivated or given the space to home grow our international leaders. Sadly, we are known for our riots. But we must not forget that the internationally acclaimed Notting Hill Carnival originated from a major political crisis. It was a response to the widespread racial attacks and race riots in 1958; in 1959 Claudia Jones established the first carnival to mark the depressing state of race relations.

EP: It's interesting that you identified with boys when you were growing up because you're also featured in Del LaGrace Volcano and Ulrika Dahl's book Femmes of Power: Exploding Queer Femininities. Do you perceive your gender as fluid?

VJM: I go to the Michigan Womyn's Musical Festival, which is not seen as a politically correct thing to do in the queer community because it excludes transgender women. It's a lesbian feminist, women-only event for 'womyn born womyn'. But it was there that I discovered the woman I want to be. In a totally free world, I'd most likely be high femme, but I'm not because it would attract too much attention from men. Also, there is 
a part of me that likes to play with gender. I can be very boyish, and the other night I went to a party dressed as a butch gangster. But I love being a woman.

EP: You often blend different genres in your work, fusing fact, fiction and fantasy. What motivates your rejection of realism?

VMJ: I grew up around a lot of dysfunctional people. There were some really disturbed people in the assessment centres I was sent to. They were in other worlds. I use fantasy to explore those worlds, to explore dysfunction. Also, because of how I grew up, a black child in a white community, I look at the world differently. My view isn't normative, I look at the world through a different lens.

EP: Does your interest in mime and physical theatre suggest a mistrust of language?

VMJ: Language is more than just words. Through mime and physical theatre, I learned to use colour as a form of expression. I'm interested in emotion, and mime and physical theatre express that. Also, I'm interested in subtext: what people don't say, or what they say with the body. I'm interested in splitting, the way in which people can say one thing but mean another, or way in which people can be in one place physically but mentally somewhere else. I'm fascinated by the mind, how it works. That's what I try to capture in my work.

EP: Your different names reflect your multiple facets as a writer. Is naming part of a process of self-definition or reinvention for you?

VMJ: I have three names now: Valerie Mason-John, Vimalasara (my Buddhist name), and Queenie. In the kids' home, I was also known as 'Gruesome'. I didn't know what it meant at the time but I knew it wasn't a nice name. So I went through a period of wanting to change my name. I like 'Queenie' - it's a fun name. Mason-John is my mother's name. It sounds like a white, middle-class name but it's from Sierra Leone, where compound names are common. However, it's a slave name - I'm descended from slaves. I feel less and less like a 'Valerie': 'Valerie Mason-John' is just my pen-name now. Naming is linked to uprooting and re-rooting. In my next novel, one of the narrators is a plant, which is 
uprooted, relocated, and renamed. However, 'Who am I?' is a universal question and all people reinvent themselves.

EP: Why was Borrowed Body republished as The Banana Kid?

VMJ: Even though Borrowed Body won the Mind Book of the Year Award, Serpent's Tail wanted me to pay to keep it in print, so I took advice from the Author's Society and asked for the rights back. I then offered the book to the British Association of Adoption and Fostering (BAAF), who wanted to change the title to The Banana Kid.

EP: Did BAAF change the cover too? The image on the front of the book [the back view of a young black girl walking down a street alone] suggests that it is being marketed as a misery memoir now.

VMJ: Yes. The title Borrowed Body signals that the book is literary fiction whereas The Banana Kid makes it sound more like autobiography. That's a compromise, but one worth making to keep the book in print.

EP: Despite the success of Zadie Smith and Andrea Levy, do you think that publishers and perhaps even some readers - want to put black British women writers in a particular literary box, one associated with personal experience rather than art?

VMJ: Well, yes, of course. Black writers appear in the 'black' section of book stores, and if we're lucky women may end up in the 'women's' section. There is much pressure on black writers to be seen to be writing about black issues. bell hooks in the USA speaks about this - there is an expectation on black writers to produce particular narratives, but things are changing too.

EP: Englishness is a key theme in your work, and your attitude to Englishness is complex. For example, you told Deirdre Osborne that after emigrating to Canada you were suddenly seen as 'English', something you disliked,58 preferring to define yourself as 'British', but you recently asserted in a blog on your website entitled 'Proud to be 
English' (March 27, 2010) that for the first time in your life you feel that you can 'own' Englishness. What prompted this change?

VMJ: Growing up in England I was never made to feel English, because I was always told to go home by racists. If I was ever asked where I was from and I said 'England', the questioner would say 'No, where are you from?' What they wanted to hear was 'Africa'. When they heard my parents were from Africa the questioner would proceed, 'So what is Africa like?' This was the narrative of my origins right up until I left the UK. In fact, I remember that, when travelling during my gap year, people in Europe did not believe black people came from England. I had to have stepped off a plane either from Africa or America. Now, in Canada, all people hear is the English accent. They think I speak fantastic English, although those who are sussed know I am English. It's hard to deny I'm English when in America or Canada because my language, the words I use, contextualise me. Plus there is bonding between English people outside of England. In my local bank, one of the workers was recently reminiscing with me about bonfire night, something typical to English culture. Also, in Canada I have more respect as a black person than I get in the UK. The fact that I have an MA and honorary doctorate puts me above the average traditionally educated person. Canadians have a healthy or unhealthy respect for Brits, which makes it possible for me to be proud to be English. I'm no longer at the bottom of the social pile; in Canada, a lot of the stigma that is attached to blacks in Britain is foisted upon the first nations community. On one level I like that I can have an identity that isn't questioned anymore, I can own Englishness without it being questioned, but then being proud to be English means I also have to take on all the unsavoury things that England has done in the name of the empire. So being proud to be English is a koan for me.

EP: You were born in Britain and have lived in Australia, India, and North America, but have described Africa as 'home'. How do you define 'home'? What determines the location of home for you?

VMJ: It's always changing, especially now that I've moved to Canada. Diaspora is at the centre of my life, which means there are many homes. England is home because that's where my history is. Africa, or Sierra Leone, is also home because that's where I 
originate from. I have several families, too. I have the foster family, the children's home family...

EP: And now a Buddhist family?

VJM: Yes, a Buddhist family. So, home means many different things. Really, home for me is here in my body.

EP: Is homelessness always a negative state or can it be positive too? Do possibilities arise from unbelonging?

VJM: Most definitely. Homelessness brings enquiry, the potential to query. I've always been homeless - literally as well as metaphorically. I have lived on the streets, and I chose to be homeless in order to take care of myself because my home wasn't safe. For some people, homelessness is about survival.

EP: Your work challenges myths about home, the idea that home is a place of security.

VJM: Having grown up in an orphanage, I am fascinated by other people's families, and I now understand that I had a lot more than some people who grew up in traditional families. I had stability. When people who come from a 'normal' family learn that I grew up in an orphanage, they sometimes say, 'Oh, you poor thing' but when I hear about their lives I think, 'No, you poor thing'.

EP: Fathers don't feature much in your work, do they?

VJM: I don't know anything about my own father and I was brought up by women: my foster mother, my biological mother, and there were two mother-figures in the children's home. There's a father in my next novel and men play a bigger role. At one point I did try to find out about my father but then I let go of that desire. I think that freed me to write more about men. I now feel more interested in uncovering the truth about men rather that colluding with the idea that men are the enemy. Men have not 
been the only oppressors in my life. My unpublished poem 'Playing Dead' is about the sexual abuse of a daughter by a mother.

EP: What's your view of transracial and transnational adoption?

VJM: I was involved in the move to ban trans-racial adoption with Lemn Sissay in the 1980s. My partner and I have discussed adoption and we have looked at other countries but I believe that children need to be adopted by someone within their own country. People can give love, but children need their own culture, not just Western privilege.

EP: Your writing takes diverse forms: journalism, plays, poetry, short fiction, novel, blog. What determines your decision to tell a story in a particular form?

VJM: Accessibility. It's about reaching different audiences and as many people as possible.

EP: What are you working on at the moment?

VJM: I am doing some research on slavery in Canada. I am working on the story of a wife of a slave-master who falls in love with her black female slave, and absconds with her lover by passing as a man. They survive by working as a circus act. I see this story visually, so I think it'll be a film.

I see myself as a writer rather than as a performer now, although I think I'll probably be remembered best for my hats and clothes. A woman once told me, 'I know you,' and then listed every outfit I have ever worn to a Pride march. I laughed.

\footnotetext{
${ }^{1}$ Valerie Mason-John, 'Uncensoring my Writing' in Dimple Godiwala ed., Alternatives within the Mainstream: British Black and Asian Theatres (Newcastle: Cambridge Scholars Press, 2006), 397-401, p. 397.

2 Valerie Mason-John, Detox Your Heart (Birmingham: Windhorse, 2005), p. 6.

${ }^{3}$ Ibid., p. 398.

${ }^{4}$ Valerie Mason-John, Brown Girl in the Ring in Deirdre Osborne ed., Hidden Gems (London: Oberon, 2008), 287-316.
} 
${ }^{5}$ Valerie Mason-John, Sin Dykes in Brown Girl in the Ring: Plays, Prose and Poems (London: Get a Grip, 1999), 99-112.

${ }^{6}$ Valerie Mason-John, The Banana Kid (2005. London: BAAF, 2008).

${ }^{7}$ Mason-John's unpublished plays are held in the Black British Theatre Archive at the National Theatre.

${ }^{8}$ The film Skin (2008), directed by Anthony Fabian, likewise explores the phenomenon of polygenic inheritance that produces what is sometimes referred to as racial 'throwbacks' through the true story of Sandra Laing, a black woman born to white Afrikaner parents during the Apartheid era.

${ }^{9}$ Paul Gilroy, 'There Ain't No Black in the Union Jack': The Cultural Politics of Race and Nation (London: Hutchinson, 1987).

10 'Uncensoring my Writing', p. 399.

${ }^{11}$ Valerie Mason-John, 'Background Notes', Brown Girl in the Ring in Osborne, p. 288.

${ }^{12}$ Savitri Hensman, 'Presentation of Self as Performance: The Birth of Queenie aka Valerie Mason-John' in Nina Rapi and Maya Chowdry eds., Acts of Passion: Sexuality, Gender and Performance (London:

Harrington Park Press, 1998), 209-219, p. 217.

${ }^{13}$ Brown Girl in the Ring: Plays, Poems and Prose, p. 2.

${ }^{14}$ Valerie Mason-John, 'Aesthetics of the Trans-Raised Diasporic Black British' in R. Victoria Arana ed., 'Black' British Aesthetics Today (Newcastle: Cambridge Scholars Press, 2007), 337-344, p. 342. Other transracially-raised black British writers such as Jackie Kay, Lemn Sissay, Mojisola Adebayo, Patience Agbabi and Alex Wheattle also explore this issue in their work.

${ }^{15}$ See the extract from The New Nation review before the novel's title page.

${ }^{16}$ Gabriele Griffin, 'Giving an Account of One's Self: Valerie Mason-John's Brown Girl in the Ring (aka

Sweep It Under the Carpet) in Deirdre Osborne ed., Hidden Gems (London: Oberon, 2008), 280-286, p. 281.

${ }^{17}$ Stuart Hall, 'New Ethnicities' in James Donald and Ali Rattansi eds., Race, Culture and Difference (London: Sage, 1992), 252-259, p. 254.

${ }^{18}$ Gabriele Griffin, Contemporary Black and Asian Playwrights in Britain (Cambridge: CUP, 2003), p. 185.

${ }^{19}$ According to the 'London Slang' website, 'off your box' means 'to be drunk or stoned'.

At http://www.londonslang.com/db/b/ accessed 12 April, 2010.

${ }^{20}$ In a note that accompanies the play, Mason-John explains that 'clart' means 'sanitary towel' (p. 42).

${ }^{21}$ Claire E. Alexander, The Art of Being Black: The Creation of Black British Youth Identities (Oxford:

Clarendon Press, 1996), p. 18.

${ }^{22}$ Susheila Nasta, 'Beyond the Millennium: Black Women's Writing', Women: A Cultural Review 11 (2000), 71-76, p. 75.

${ }^{23}$ Jayne O. Ifekwunigwe, 'Diaspora's Daughters, Africa's Orphans?: On Lineage, Authenticity and "Mixed Race" Identity' in Heidi Safia Mirza ed., Black British Feminism: A Reader (London: Routledge, 2007), 127152, p. 141.

${ }^{24}$ José Esteban Muñoz, Disidentifications: Queers of Color and the Performance of Politics (Minneapolis: University of Minnesota Press, 1999), p. 31, p. 108.

${ }^{25}$ Mason-John identifies the play's 'drag aesthetic' in a discussion with Mojisola Adebayo and Deirdre Osborne. See Deirdre Osborne, '"No Straight Answers: Writing in the Margins, Finding Lost Heroes', Theatre Quarterly 97.1 (Feb. 2009), 6-21, p. 12.

26 Muñoz, p. x. Muñoz takes the term 'pasty normals' from Jack Smith.

${ }^{27}$ Brown Girl in the Ring: Plays, Prose and poems, p. 91. This is a theme to which Mason-John returns in The Banana Kid when Pauline's half-sister, Shola, newly arrived from Africa, declares that she is a 'princess' in the Yoruba chiefdom (p. 160).

${ }^{28}$ See Hensman, p. 214.

${ }^{29}$ Judith Halberstam, Female Masculinity (Durham: Duke UP, 1998), p. xi; p. xii.

30 ibid., p. 2.

${ }^{31}$ Valerie Mason-John qtd. in Del LaGrace Volcano and Ulrika Dahl eds., Femmes of Power: Exploding Queer Femininities (London: Serpent's Tail, 2008), p. 33.

${ }^{32}$ See Brown Girl in the Ring: Plays, Prose and Poems, p. 21.

${ }^{33}$ Femmes of Power, p. 33.

${ }^{34}$ See Valerie Mason-John, 'Keeping Up Appearances: The Body and Eating Habits' in Nicola Godwin, Belinda Hollows and Sheridan Nye eds., Assaults on Convention: Essays on Lesbian Transgressors (London: Cassell, 1996), 65-79, p. 79.

35 Judith Butler, Bodies That Matter: On the Discursive Limits of 'Sex' (London: Routledge, 1993), p. 73; p. 79; p. 62.

36 ibid., p. 64.

37 ibid., p. 91. 
${ }^{38}$ Brown Girl in the Ring: Plays, Prose and Poems, pp. 8-9.

${ }^{39}$ R. Victoria Arana, 'Sea Change: Historicizing the Scholarly Study of Black British Writing' in R. Victoria Arana and Lauri Ramey eds., Black British Writing (London: Palgrave Macmillan, 2004), 19-45, p. 33. ${ }^{40}$ See 'English Rose' (9 April, 2010), at http://valeriemason-john.com/, accessed 12 April, 2010.

${ }^{41}$ Mason-John examines the specific relationship between lesbians and eating disorders in her essay 'Keeping Up Appearances'. She discusses her own experience of bulimia, and how she overcame this condition, in her self-help book Detox Your Heart (Birmingham: Windhorse, 2005).

42 Detox Your Heart , p. 5.

${ }^{43}$ Lemn Sissay, 'Before We Get Into This' in Listener (Edinburgh: Canongate, 2008), p. 38.

${ }^{44}$ Avtar Brah, Cartographies of Diaspora: Contesting identities (London: Routledge, 1996), p.180.

${ }^{45}$ Anne Marie-Fortier, 'Coming Home: Queer Migrations and Multiple Evocations of Home', European Journal of Cultural Studies 4.4 (2001), 405-424, p. 408.

${ }^{46}$ Ibid., pp. 406-7. James Proctor, Dwelling Places: Postwar Black British Writing (Manchester: MUP, 2003), p. 14.

${ }^{47}$ Brown Girl in the Ring: Plays, Prose and Poems, p. 1.

48 Ibid., p. 4.

${ }^{49}$ Maggie Gee, 'Bringing the Head and Body Together: Valerie Mason-John and Dorothea Smartt in

Conversation', Wasafiri 22.1 (2007), 14-20, p.17.

${ }^{50}$ Hall, 'New Ethnicities', p. 258.

${ }^{51}$ See Bernadette Halpin and Dorothea Smartt eds., Words from the Women's Cafe: Lesbian Poetry from 'Word Up' (London: Centerprise Publications, 1993).

${ }^{52}$ See Lynette Goddard, Staging Black Feminisms: Identity, Politics, Performance (Basingstoke: Palgrave, 2007) for a fuller discussion of realism in black feminist theatre, and Mason-John's relationship to earlier black British lesbian playwrights such as Jackie Kay.

${ }^{53}$ Gee, 'Bringing the Head and Body Together', p. 19.

54 Valerie Mason-John, 'Toxins' in Rajeev Balasubramanyam with Courttia Newland eds., Tell Tales Volume II (London: Tell Tales, 2005), 151-155.

${ }^{55}$ Salman Rushdie, Imaginary Homelands: Essays and Criticism 1981-1991 (London: Penguin, 1992).

56 Isaac Julien's film Young Soul Rebels (1991) focuses on two young black men, Caz (who is gay)and Chris (who is straight), aspiring soul DJs known as 'Soul Patrol'. Set in London against the backdrop of the Queen's Silver Jubilee celebrations, the film explores racism and homophobia in Britain in the late 1970s, epitomised by the murder of a gay black man at the start of the film and a series of hostile encounters between soul boys and skinheads. Yet, reflecting the radial potential for resistance and rebellion articulated by the graffiti slogan 'black and white unite and fight', adapted by Caz's punk lover to 'black and white unite and fuck', the film explores music's ability to bring people together, overcoming difference without erasing it, as well as the subversive possibilities engendered by inter-racial same-sex desire.

57 'Blues' are parties that take place in a private house. An entrance fee is paid at the door, and people pay for drinks at a bar inside. A 'shabeam' is an illegal club. This is Mason-John's spelling, a variant of 'shebeen'.

58 Osborne, 'No Straight Answers', p. 16. 